\title{
Studies of current collection configurations and sealing for tubular hybrid-DCFC
}

Alfredo Damiano Bonaccorso, Cairong Jiang, Jianjun Ma and John TS Irvine*

School of Chemistry, University of St Andrews, St Andrews, Fife, KY16 9ST, United Kingdom

\begin{abstract}
Direct Carbon Fuel Cells (DCFC) offer efficient conversion of coal or biomass derived carbons to electricity. A Hybrid Direct Carbon Fuel Cell (HDCFC) is a type of DCFCs that combines solid oxide cell geometry with a molten carbonate fuel cell electrode. This study focused on investigating different current collection configurations and sealant for tubular HDCFC concept. A HDCFC used a gadolinia doped ceria (GDC) or a YSZ as the electrolyte, in composites with $\mathrm{NiO}$ and LSM as the anode and the cathode, respectively. Three different current collection configurations of HDCFC were investigated by AC impedance in order to study the electrochemical phenomena that occur at the electrodes surface. The AC impedance results showed that both the surface area and the position of the current collector inside of the anode chamber affect drastically both the series resistance $\left(R_{s}\right)$ and the polarisation resistance $\left(R_{p}\right)$ values. The lowest total resistance $\left(R_{\text {tot }}\right)$ was achieved on Configuration $b$ with silver wire interwoven nickel mesh attached to the side of the anode wall by silver paste $\left(\mathrm{R}_{\text {tot }}=2.98 \Omega\right)$ and while the highest $\mathrm{R}_{\text {tot }}$ was achieved on the configuration $\mathrm{c}$ with silver wire interwoven nickel mesh inserted into the mixture of carbon and carbonate $\left(R_{\text {tot }}=149 \Omega\right)$. The leak test carried out on several sealants demonstrated that composite sealants of Toku P-24 paste and an alumina silicate disc produced a low degree of leaks due to both the high resistance to the carbonate mixture and high density sealing after curing compared to the ceramabond.
\end{abstract}

Keywords: Fuel Cell, DCFC, Sealant, CGO, LSM, Current collector

*Corresponding author:

Email: jtsi@st-andrews.ac.uk

North Haugh - St Andrews- Fife - KY16 9ST- United Kingdom

Tel: +44 1334463817 Fax: +44 1334463808 


\section{Introduction}

Fuel cells are electrochemical devices that convert the chemical energy in fuel into electric energy directly, promising power generation with high efficiency and low environmental impact because they prevent the formation of $\mathrm{NO}_{\mathrm{x}}$ that occurs in gas turbine devices (1). Different types of fuel cells are studied in the energetic research field, but little attention has been paid to direct carbon fuel cells (DCFCs) despite the fact that the energy released upon the electrochemical oxidation of carbon to $\mathrm{CO}_{2}(23,95 \mathrm{kWh} / \mathrm{l})$ exceeds that of most other non-solid fuels (e.g. hydrogen, methane and diesel) (2) and also carbon materials are available from many sources (for example, coal, carbon obtained from biomass pyrolysis and plastic materials and hydrocarbon cracking).

Different types of DCFCs have been developed and a hybrid direct carbon fuel cell (HDCFC) is the one that has been developed in recent years (1)(3-6). This new concept emerged from the intrinsic difficulty of implementing carbon fuels whereby most carbon fuel cells require a solid membrane with a solid fuel. There is indeed very little interaction between the solid fuel and the solid electrode/electrolyte membrane. This hybrid concept could solve this problem using a solid electrolyte with a fuel electrode/electrolyte based on a slurry of liquid electrolyte (62:38 mol. eutectic mixture of $\mathrm{Li}_{2} \mathrm{CO}_{3}$ and $\left.\mathrm{K}_{2} \mathrm{CO}_{3}\right)$ and carbon electrode as shown in Figure $1(1)(7,8)$.

This liquid avoids the solid/solid contact problem (9), however, the presence of molten carbonate in the anode chamber can affect the electrochemistry in two different ways: Firstly, it extends the surface area of the anode as the molten carbonate acts as a mediator in the oxidation of carbon fuel. These reactions take place not only at the solid surface of the anode but also throughout the anodic chamber. Secondly, molten carbonate might react with the sealant, eventually leading to gas leaks. All of these aspects have to be studied in order to improve the overall performance.

\section{Experimental}

\subsection{Materials and Methods}

$\mathrm{Ce}_{0.9} \mathrm{Gd}_{0.1} \mathrm{O}_{1.95}$ powder with $7.08 \mathrm{~m}^{2} \mathrm{~g}^{-1}$ surface area (Praxair), $\left(\mathrm{Y}_{2} \mathrm{O}_{3}\right)_{8}\left(\mathrm{ZrO}_{2}\right)_{92}(8 \% \mathrm{YSZ} \mathrm{Pi}-\mathrm{Kem})$, $\left(\mathrm{La}_{0.8} \mathrm{Sr}_{0.2}\right)_{0.95} \mathrm{MnO}_{3} 99.9 \%$ (LSM Pi-Kem) and $\mathrm{NiO} 325$ mesh (Sigma-Aldrich) were used as components. Tapes were produced using polyethylene glycol, dibutyl phthalate, butvar and a mixture of solvents in ratio 3:1 methyl ethyl glycol and ethanol.

The medium density fiberboard (mdf) was pyrolysed at $500{ }^{\circ} \mathrm{C}$ and ground to yield a surface area of $10 \mathrm{~m}^{2} \mathrm{~g}^{-1}$. This $\mathrm{p}-\mathrm{MDF}$ consisted of $69 \%$ carbon with $5 \%$ nitrogen and $4 \%$ hydrogen in weight 
percentage, and was used as fuel for the cell. Lithium carbonate (Aldrich) and potassium carbonate (Fisher) were mixed in a mole ratio of $62 \%$ and $38 \%$ to prepare the eutectic mixture which was used as the secondary electrolyte/electrode in the device. Eutectic mixtures were mixed with p-MDF carbon in a mole ratio of 80:20. Then, the mixture was dried at $100{ }^{\circ} \mathrm{C}$ overnight in an oven. The dried carbon mixture was packed into the anodic compartment. Two sealant pastes based on alumina silicate such as Toku ceramics P-24 (TOKU Ceramics) and ceramabond 552(Aremco) and rigid sealant such as thermiculite 866 (Flexitallic), combined with glass wool disks, were used for sealing.

\subsection{Cell design and preparation}

Green tapes of a NiO-GDC (containing $70 \mathrm{wt} \%$ ) anode, a GDC electrolyte, a cathode (LSM GDC) and a LSM 3\% from Pi-Kem were produced. The oxide powders were homogenized in a mixture of methyl-ethyl- ketone and ethyl alcohol at ratio 3:1, using zirconia balls. The slurry was milled for $18 \mathrm{~h}$ at $160 \mathrm{rpm}$; then, after adding the organic component, it was shaken for $22 \mathrm{~min}$ and milled again for $4 \mathrm{~h}$ at $100 \mathrm{rpm}$ after adding the organic component. The same procedure was used for electrolyte slurry preparation, but an overnight milling was added to eliminate possible air bubbles during tape casting process.

As-prepared slurries were tape-casted on a TTC-1000, from Mistler Inc, by standard tape casting processing. The tape was casted at room temperature with a carrier velocity of $50 \mathrm{~cm} / \mathrm{min}$. Laminates were then assembled as shown in Fig.2:

The cells were sintered in two different steps. In the first step the organics and carbon in the green cells were burnt out heating to $1000{ }^{\circ} \mathrm{C}$, using a ramp rate of $1{ }^{\circ} \mathrm{C} / \mathrm{min}$. The temperature was held at $1000{ }^{\circ} \mathrm{C}$ for 5 hours and the cells were cooled down to $50{ }^{\circ} \mathrm{C}$ using a ramp rate of $5{ }^{\circ} \mathrm{C} / \mathrm{min}$. In the second step, cells were sintered at $1410{ }^{\circ} \mathrm{C}$ with a ramp rate of $5{ }^{\circ} \mathrm{C} / \mathrm{min}$, as this procedure was found to give good electrolyte conductivity (10). The temperature was held for 5 hours and it was then cooled down to $50{ }^{\circ} \mathrm{C}$ at $5^{\circ} \mathrm{C} / \mathrm{min}$. The final size of each cell was $8 \mathrm{~cm}$ height and $1.1 \mathrm{~cm}$ diameter with the thicknesses of anode, electrolyte and cathode layers being $60 \mu \mathrm{m}, 200 / 300 \mu \mathrm{m}$ and $60 \mu \mathrm{m}$ respectively. Silver wire, silver paste and Ni-mesh were used to make the electrical contacts in the anode, while silver paste and silver wire were used as electrical contacts on the cathode side. After the electrical contacts were made, each cell was filled with the carbon/carbonate mixture described previously. Two $15 \mathrm{~cm}$ long stainless steel tubes (one gas outlet and one inlet) were inserted into the anode chamber in $1 \mathrm{~cm}$ deep. 


\subsection{Preparation of electrical configurations}

As explained previously, a hybrid direct carbon fuel cell is a merger between a fuel cell with a solid electrolyte and a solid carbon with a molten carbonate electrolyte. In the anodic chamber, the dimension of the anode is not only limited to the NiO-GDC layer but it is extended to the liquid zone consisting of a carbon and carbonate mixture. Consequently, electrochemical reactions can take place in any part of the anode chamber, including in the carbon and carbonate mixture, as shown in the equations below:

$\begin{array}{cc}\mathrm{C}+2 \mathrm{O}^{2-} \rightarrow \mathrm{CO}_{2}+4 \mathrm{e}^{-} & \text {eq. } 1 \\ \mathrm{C}+\mathrm{O}^{2-} \rightarrow \mathrm{CO}+2 \mathrm{e}^{-} & \text {eq. } 2 \\ \mathrm{CO}+\mathrm{O}^{2-} \rightarrow \mathrm{CO}_{2}+2 \mathrm{e}^{-} & \text {eq. } 3\end{array}$

Oxidation of carbon fuel via carbonate salts

$\mathrm{C}+2 \mathrm{CO}_{3}^{2-} \rightarrow 3 \mathrm{CO}_{2}+4 \mathrm{e}^{-} \quad$ eq. 4

$\mathrm{C}+\mathrm{CO}_{3}^{2-} \rightarrow \mathrm{CO}+\mathrm{CO}_{2}+2 \mathrm{e}^{-} \quad$ eq. 5

For this reason, different electrical configurations for the anode were investigated so as to determine the zone of the anode in which these reactions take place, improving the performance of the cell. The configurations investigated are shown in Figures 3a, $3 \mathrm{~b}$ and $3 \mathrm{c}$ :

In the configurations shown above, silver wire, silver paste and nickel mesh are the current collectors. Differences between these configurations and the setting are characterized by their positions inside the anodic chamber and also by the size of the current collector. Configuration a of the current collectors has silver wire pasted with silver paste; they are attached to the side of the anode wall (Figure 3a). Configuration b has silver wire interwoven nickel mesh; they attached to the side of the anode wall by silver paste. Configuration $\mathrm{c}$ has silver wire interwoven nickel mesh; they are inserted into the mixture of carbon and carbonate. The aim of this is to determine the contribution of electrons produced by reactions shown in eq. 4 and eq. 5 .

\subsection{Sealing procedure}

The electromotive force of the fuel cell is represented by the difference of chemical potential between the reduction reaction of oxygen to oxygen ions which takes place at the cathode side and the chemical potential of the reaction between carbon and oxygen ions which take place in the 
anodic chamber. Therefore, the electromotive force is affected by the partial pressure of gas in the anodic chamber and in the cathode side. If the oxygen partial pressure is constant in the cathode side, the variation in EMF can be caused by the decrease of oxygen partial pressure in the anode side. For this reason, a good sealant with good acid resistance properties and high barrier gases is required for this type of cell. When the cell apertures have had sealant fully applied, three possible leakages could occur: leaks along the surface contact, osmosis leaks and break-down leakage. Fig 4:

Break-down leaks occur when the cement bursts, due to high pressure and/or corrosion $(11,12)$. The cells used to investigate the three different electrical configurations were sealed with 552 ceramabond supplied by Aremco in order to keep the same parameters of previous tests (8). The utilization of different sealants was investigated in order to decrease the leaks observed during the tests carried out on the three different electrical configurations using the ceramabond 552. The investigations were carried out both on ceramabond 552 and on new ceramic alumina paste P-24 produced by ToKu Adhesive Ltd. The cell with the second configuration shown in Figure 3 was chosen to test both sealants. Two types of procedures, procedure A and B, were chosen to seal the cells: Procedure A was carried out sealing the apertures of the cell with P-24 or ceramabond 552 and then they were cured. The glass P-24 was dried and cured at room temperature for $24 \mathrm{~h}$ while ceramabond 552 was dried at room temperature for $1 \mathrm{~h}$ and then it was cured at two temperatures: $94^{\circ} \mathrm{C}$ for $2 \mathrm{~h}$ and at $204^{\circ} \mathrm{C}$ for $4 \mathrm{~h}$. Procedure B was carried out, utilising two additional flexible alumina discs that were added to the alumina paste in order to reduce gas diffusion through the materials. The materials used were alumina fibre papers and a disc of mica, produced by Thermiculite 886 (Flexitallic Ltd). Thermiculite 866 (Flexitallic Ltd) is a composite material consisting of chemically exfoliated vermiculite mica. Mica is a group of silicate minerals with a general structure of $\mathrm{AB}_{2-3} \mathrm{Z}_{4} \mathrm{O}_{10}(\mathrm{OH}, \mathrm{F})_{2}$ in which $\mathrm{A}$ is $\mathrm{K}, \mathrm{Na}, \mathrm{Ca}$ or $\mathrm{Ba}$ and $\mathrm{B}$ is either $\mathrm{Al}, \mathrm{Fe}$, $\mathrm{Mg}$ or Li [11-13]. The procedure B is schematised in Figure 5:

\subsection{Corrosion test}

Tests of resistance to carbonate were carried out on the sealant. The sealant materials, previously cured following the parameters previous indicated, was insert into an alumina crucible with carbonate a mixture of $\mathrm{Li}-\mathrm{K}$ carbonate in a mole ratio of 62:38. The alumina crucible was heating up to $800{ }^{\circ} \mathrm{C}$ and the sealant was held direct contact with the carbonate for $72 \mathrm{~h}$. The crucible contained both carbonate salts which were closed using a top (maccor). A flow rate of $25 \mathrm{ml} / \mathrm{min}$ of $\mathrm{CO}_{2}$ was used to prevent the decomposition of carbonate at high temperatures. 


\subsection{Investigation of leaks in the cell}

The open circuit voltage (OCV) of a cell provides information about the electrochemical potential produced by the reactions in eq. 1, 2 and 3 that take place in the anode chamber. The overall EMF was estimated at $1.02 \mathrm{~V}$ for the three reactions mentioned above, using a thermodynamic approach which makes use of the $\Delta \mathrm{G}$ value estimated using FactSage software. The EMF obtained previously was recalculated using the ratio between $\mathrm{CO}$ and $\mathrm{CO}_{2}$ at the equilibrium obtained by gas chromatography at $700{ }^{\circ} \mathrm{C}$. The ratio achieved was $3: 1$. This value was inserted into the FactSage software in order to estimate the value of $\mathrm{PO}_{2}$ at the anode side. EMF was obtained using equation 6.

$$
\mathrm{EMF}=-\frac{\mathrm{RT}}{4 \mathrm{~F}} \ln \frac{\mathrm{P}_{\mathrm{O}_{2, \mathrm{c}}}}{\mathrm{P}_{\mathrm{O}_{2, \mathrm{a}}}}
$$

Where $\mathrm{P}_{\mathrm{O}_{2, \text { c. }}}$ and $\mathrm{P}_{\mathrm{O}_{2, a} \text {, }}$ are the partial pressures of oxygen in the cathode and anode sides, respectively. These calculations were done assuming the system and the gas concentration remained constant. The value obtained by this calculation was $0.97 \mathrm{~V}$, which is $5 \mathrm{mV}$ less than the value estimated using the $\Delta \mathrm{G}$ of each reaction involved. These values were considered the maximum and minimum limits. Since the temperature of the system, the ratio of carbon to carbonate and gas composition in the cathode were the same, the variation of EMF may be caused by electron leaks and gases leaks. If the voltage value changes as a function of time, a leak is present in the system. Since GDC is an electronically conductive material at temperature of upper than $600{ }^{\circ} \mathrm{C}$, tests were carried out using two different electrolyte supported cells: one of these used a YSZ electrolyte which was a total ionic conductor and for this reason it produced no current leaks, while the second cell used a GDC electrolyte. The tests were carried out with $40 \mathrm{ml} / \mathrm{min}$ air in the cathode side.

\subsection{Electrochemical investigation}

Electrical performances of each cell were tested using a (Solartron 1280B) and AC impedance spectra recorded between $20 \mathrm{kHz}-0.1 \mathrm{~Hz}$ at an amplitude of $10 \mathrm{mV}$. Before starting each test, the samples were heated from $50{ }^{\circ} \mathrm{C}$ to $650{ }^{\circ} \mathrm{C}$ at $5{ }^{\circ} \mathrm{C} / \mathrm{min}$. The cell was then held at $650{ }^{\circ} \mathrm{C}$ for 10 mins to allow it to equilibrate. Usually measurements were conducted at intervals of $50{ }^{\circ} \mathrm{C}$ to 750 ${ }^{\circ} \mathrm{C}$. The open circuit voltage was measured as a function of the time in order to estimate leaks. 


\section{Results and discussion}

\subsection{Electrochemical investigation of three different electrical configurations.}

Three different current collection configurations were set on three tubular cells that were loading with the mixture of carbon and carbonate and sealed by ceramabond 552 following the procedure A, previously illustrated.

Figure 6 shows the AC impedance of three different cells with the three current collection configurations $\mathrm{a}, \mathrm{b}$ and $\mathrm{c}$, as described in experimental section.

The ac impedance data show that the electrochemical behaviour of the each cell is affected by the different current collector configurations in the anodic chamber as the different values of the series resistance $\left(R_{s}\right)$ and the polarization resistance $\left(R_{p}\right)$, were achieved for these three cells with the same composition of anode, electrolyte and cathode. Even though the cells are identical, it is clearly observable from the ac impedance analysis that there is a large difference between Configuration a, $\mathrm{b}$ and Configuration $\mathrm{c}$.

These differences might be mainly explained by the different surface area, position and current collector used. Analyzing the ac impedance the configuration a and $b$ show a large difference in $R_{s}$ at $650{ }^{\circ} \mathrm{C}$ which is drastically reduced when the temperature is increased to $700{ }^{\circ} \mathrm{C}$ and $750{ }^{\circ} \mathrm{C}$. This marked difference at $650{ }^{\circ} \mathrm{C}$ might be attributed to both a low mediator activity of the molten carbonate which is not completely melted at that temperature and the surface area of the current collector. In fact, the molten carbonate which is not totally melting causing a limitation on diffusing the gases produced in the reaction 4 and 5 and carbon particles from the centre of the anode chamber to the current collector stuck on the anode wall. Whereas, the surface area of the current collector limits the electron collection of the electrochemical reaction that take place at the wall (14-15).

To understand what type of electrochemical phenomena and mechanisms of reaction occur at the anode side and motivated strongly the hypothesis provided above an analysis of $R_{s}$ and $R_{p}$ was done. The natural logarithmic values of $R_{s}$ and $R_{p}$ extrapolated from AC impedance by Zview were plotted as a function of $1 / \mathrm{T}$ and the activation energy of each configuration was calculated as shown in Figures 7a and 7b.

By analyzing the $R_{s}, R_{p}$ and activation energy of each configuration, calculated by Arrhenius equation, interesting results were obtained. The configuration $\mathrm{c}$ shows activation energy equal to $E_{a}=-0.77 \mathrm{eV}$ for $R_{s}$ and $E_{a}=1.03 \mathrm{eV}$ for $R_{p}$ which are in accord with the potential values for the oxidation of $\mathrm{Ni}$ metal to $\mathrm{NiO}$ and the oxidation of $\mathrm{C}$ to $\mathrm{CO}_{2}$. These results highlight that the nickel mesh which is deep into the carbon/carbonate mixture also reacts with carbon fuel in the anodic 
compartment. In fact, the metal nickel mesh is oxidized by carbonate to nickel oxide which reacts with the carbon fuel as show in the equation below

$$
\begin{array}{ll}
\mathrm{Ni}+\mathrm{CO}_{3}^{2-} \rightarrow \mathrm{Ni}+\mathrm{CO}_{2}+4 \mathrm{e}^{-} & \text {eq. } 7 \\
\mathrm{NiO}+\mathrm{C} \rightarrow \mathrm{Ni}+\mathrm{CO}+2 \mathrm{e}^{-} & \text {eq. } 8
\end{array}
$$

All of the electrons produced at the anode surface for eq. 1 and 3 are not collected to the current collector because of the low conductivity of the carbon fuel (mdf) and molten carbonate salts. In addition, nickel metal is highly reactive with carbonate and as it is in direct contact with the carbonate, dissolution phenomena of nickel are visible. (15-16)

All of these hypothesizes explain the high resistance and the low current for the third configuration. The situation is more complicate for Configurations a and $b$ because different reactions occur on the current collector and at the anode surface.

Two different activation energy values $\left(E_{a}=-0.1 e V\right.$ and $\left.E_{a}=-1.1 e V\right)$ were calculated for $R_{s}$ in Configuration a and Configuration b respectively. The discrepancy of these values is due to surface area of the current collector and the resistance produced by solid carbon fuel in direct contact with the anode. The activation energy for Configuration a, that has a current collector with a lower surface area than Configuration b, could be attributed to the resistance of Ni-GDC anode to be in contact with the carbon fuel. This is confirmed by the significant decrease in $R_{s}$ when the temperature increased to $750{ }^{\circ} \mathrm{C}$. In fact, the high temperature decreases the viscosity of the molten carbonate that enhances the solid/solid contact between the carbon fuel and the anode.

In Configuration b, a high physical contact of the carbon and the anode is limited by the nickel mesh current collector. The nickel mesh act as a net that selects small particle of carbon and molten carbon improves the physical contact between anode and carbon fuel even at $650{ }^{\circ} \mathrm{C}$.

While the activation energy of $R_{s}$ is the product of the reactions, 1, 2 and 3 that take place at the interface between the current collector and the anode. The $\mathrm{R}_{\mathrm{p}}$ value is higher for Configuration a than $b$. This could be due to the increase of the active sites for reactions 4 and 5 in presence of the larger area of the current collection.

\subsection{Investigation of leaks by open circuit voltage.}

Figure 8 shows a marked difference between the voltage measured in the cell sealed by P-24 and ceramabond. The tests demonstrated that P-24 produced by Toku Adhesive showed better performance in sealing than Ceramabond 552 produced by Pi-Kem. This difference in voltages for the two cells could have several factors: First of all, the difference in voltage between the cell with GDC and YSZ depends on the nature of the electrolyte. In fact, YSZ is a pure ionic conductor while GDC is a partial ionic conductor. Thus, the difference in voltage is attributed to current leaks. For 
this reason, a comparison between a cell with YSZ electrolyte and GDC electrolyte was done to have a quantitative analysis between the leaks attributed to the electronic contribute of GDC at high temperature and the gas leaks. The difference in voltage between one sealant compared to the other is attributed to the effectiveness of the sealants. One of the reasons for the better performance of the P24 than ceramabond 552 is identified to the cracks or micro-cracks on the ceramic electrolyte next to the sealant. Instead, no cracks were observed in the sample sealed with P-24. Micro-cracks and cracks were due to the strong shrinkage effect produced by the sealant during the curing process. Cracks were visible during the cell manufacture while micro-cracks were not visible and cells tested showed a sharp drop in voltage at $650{ }^{\circ} \mathrm{C}$ because of the micro-pores present close to the sealant. The second reason of the better performance of P-24 than ceramabond 552 were due to the osmosis leaks through the sealant. This phenomenon could be caused by a imperfect curing of the sealant and/or corrosion mechanisms. This theory was confirmed by the SEM analysis carried out on the sealants before and after the corrosion test (Figure 9).

Figure 9 shows P-24 has a denser structure after curing than ceramabond, this explains the difference in OCV between the cell sealed by P-24 and ceramabond. The variation in porosity is more marked in ceramabond after being held for $72 \mathrm{~h}$ at $800{ }^{\circ} \mathrm{C}$ into a carbonate mixture. In fact, in P-24, corrosion occurred only on the surface of the cement while corrosion on ceramabond 552 affected both the surface and the interior, increasing the diameter of pores in the cement after contact with the molten carbonate.

\subsection{Effect of composite sealant on the OCV voltage}

The previous results and the microstructure of both samples showed that the main leakage problems were caused by the diffusion of gases that crossed the sealants, hence several types of composite sealants were investigated in order to reduce the diffusion of gases across the alumina sealants. The sealing procedure with additional flexible sealant was shown in Figure 5. The OCV was monitored in order to understand the performance of the cell sealed, adding the alumina flexible disc as shown in Figures 10.

The results obtained show that a double solid sealants, composed of mica and alumina button, reduced both the diffusion leakages and surface contact leakages, as shown above by comparing the tests carried out both on cells sealed with composite seals and without mica and alumina fibres. 


\section{Conclusion}

In this work, two important factors that affect the performance of the cell were investigated in order to improve the performance of a hybrid direct carbon fuel cell.

The first factor investigated was the current collection configurations. The results achieved highlighted that the performance of the current collector are affected by its surface area and position of the current collector inside the anodic chamber. The best performance was obtained on Configuration $\mathrm{b}$ with silver wire interwoven nickel mesh attached to the side of the anode wall by silver paste, which displayed a value of total resistance $\mathrm{R}_{\text {tot }}=2.98 \Omega$ at $750{ }^{\circ} \mathrm{C}$. This configuration improves the direct contact between the current collector and the active doubling the surface area of the current collector compared the surface area of configurations a and $c$, reducing the $\mathrm{R}_{\mathrm{s}}$.

Regarding the sealant performance the composite sealants consisting of the ceramic paste and two flexible ceramic materials show the best results than the non-composite seals. In fact, the utilization of a composite sealant in a tubular cell reduced the surface contact leak, the osmosis and break down leaks. In particular, the best performance was achieved by using the P-24 in composite with the two flexible alumina silicate discs. This result was due to both the higher resistance to carbonate and the denser structure obtained by P-24 after curing than that was shown from ceramabond 552. The difference in voltage measured using YSZ electrolyte and GDC electrolyte was only attributed to the partial electron conductivity of GDC at temperature above $650{ }^{\circ} \mathrm{C}$

\section{References}

1. Correa SM, Combustion Science and Technology. (1993); 87: 1-6, 329-362 .

2. Pointon KD, Lakeman BJ, Irvine JTS, Bradley JC, Jain SL. J. of Power Sourc.-(2006): 162; 750-756.

3. Pesavento PV US Patent (2001); No. 6,200,697

4. Cooper JF,. Krueger RL, Cherepy N, US Patent (2004) No. 6,815,105

5. Cooper JF, Cherepy N, Krueger RL. US Patent (2005) No. 6,878,479

6. Lipilin AS, Balachov II, Dubois LH, Sanjurjo A, McKubre MC, Crouch-Baker S, Hornbostel MD, Tanzclla FL, US Pat. (2006) No. 20060019132

7. Jain SL, Lakeman BJ, Pointon KD, Irvine JTS. Electrochemical society Transactions, proceeding of International Symposium SCOF X 2007,7,829

8. Bonaccorso AD. PhD thesis ,Development of tubular hybrid direct carbon fuel cell and pyrolysis of biomass for production of carbon fuel. (2013), http://research-repository.standrews.ac.uk/handle/10023/3597

9. Kudo T, Hisamitsu Y, Kihara K, Mohamedi M and Uchida I, J. Power Sources. (2002); 104: 272

10. Konysheva E, Bonaccorso AD, Irvine JTS. Russian Journal of Electrochem. (2010); 46;7: 857 11. Wypych G, Handbook of Fillers: A Definitive User's, Guide and Databook, 2nd Edn., ChemTec Publishing, Toronto, Canada (2000). 
12. Feodor Burgmann Dichtungswerke GmbH \& Co, Sealing Technol. (2000); 6: 17.

13. Threebond Technical News - Issue January 1, 2003

14. Guan WB, Zhai HJ, Jin L, Li TS, Wang WG. Fuel cells. (2011);11; 3: 445-450,

15. Jiang SP, Love JG, Apateanu L. Solid State Ionics. (2003); 160: 15-26.

16. Andrew C, Coree CG, Antunes R, Irvine JTS. Int. J. Hydrogen Energy (2013), 38:20; 84978502

17 Chien C, Arenillas A, Jiang C, JTS Irvine- J. Electrochem Soc. (2014), 161: (5); F588-F593.

\section{Captures}

Figure 1. Schematic description of a tubular hybrid direct carbon fuel cell.

Figure 2. Schematic description of the manufacturing of a tubular cell in two steps: A) laminated anode and electrolyte tapes were rolled by stainless steel tube; B) cathode and current collector were rolled respectively on anode and electrolyte green laminate.

Figure 3. Electrical configuration in the anodic chamber (a) configuration with silver wire attached directly to the anodic wall using silver paste and dried at room temperature (b) configuration with silver wire interwoven with nickel mesh and attached to the anode with silver paste (c) configuration with silver wire interwoven with nickel mesh inserted fully into the carbon/carbonate mixture.

Figure 4. Schematic description of possible leaks in a fuel cell.

Figure 5. Schematic description of sealing process in different steps: a) an alumina disk is inserted into the top part of the tubular cell b) sealant on alumina disk c) mica disk attaches to the sealants d) lateral sealing.

Figure 6. AC impedance of cell with Configuration a, b and c carried out at a range between 20 $\mathrm{KHz}-0.1 \mathrm{~Hz}$ at $10 \mathrm{mV}$ amplitude at $650{ }^{\circ} \mathrm{C}, 700^{\circ} \mathrm{C}$ and $750^{\circ} \mathrm{C}$

Figure 7. $\log (\mathrm{R})$ plotted vs temperature of a hybrid direct carbon fuel cell with three different configurations filled with a mixture of carbonate and carbon in a mole ratio of 20/80 .

Figure8. Plot of open circuit voltage as function of the time carried out on two different electrolytes supported cells (YSZ and GDC). Cells were sealed by using P-24 and ceramabond 552 following the procedure $\mathrm{A}$. The tests were carried out at $700{ }^{\circ} \mathrm{C}$ for $2 \mathrm{~h}$

Figure 9. SEM pictures of Toku adhesive P-24 and ceramabond 552 before tests (a) P-24 after curing (b) ceramabond 552 after curing. (c) P-24 after 72h (d) ceramabond 552 after $72 \mathrm{~h}$.

Figure 10. OCV curves of different HDCFCs sealed using procedure B: - (P-24+ alumina fibres and mica button) - (ceramabond $552+$ alumina fibre button and mica button). The tests were carried out at $700{ }^{\circ} \mathrm{C}$ for $2 \mathrm{~h}$. 